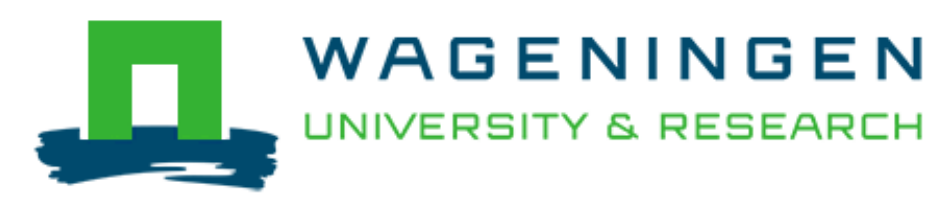

Salinity-induced increase of the hydraulic conductivity in the hyporheic zone of coastal wetlands

van Dijk, G., Nijp, J. J., Metselaar, K., Lamers, L. P. M., \& Smolders, A. J. P.

This article is made publically available in the institutional repository of Wageningen University and Research, under article 25fa of the Dutch Copyright Act, also known as the Amendment Taverne.

Article $25 f a$ states that the author of a short scientific work funded either wholly or partially by Dutch public funds is entitled to make that work publicly available for no consideration following a reasonable period of time after the work was first published, provided that clear reference is made to the source of the first publication of the work.

For questions regarding the public availability of this article, please contact openscience.library@wur.nl.

Please cite this publication as follows:

van Dijk, G., Nijp, J. J., Metselaar, K., Lamers, L. P. M., \& Smolders, A. J. P. (2017). Salinity-induced increase of the hydraulic conductivity in the hyporheic zone of coastal wetlands. Hydrological Processes, 31. https://doi.org/10.1002/hyp.11068 


\title{
Salinity-induced increase of the hydraulic conductivity in the hyporheic zone of coastal wetlands
}

\author{
Gijs van Dijk ${ }^{1,2}$ | Jelmer J. Nijp ${ }^{3,4,5}$ | Klaas Metselaar ${ }^{4}$ | Leon P.M. Lamers ${ }^{2,1}$ | \\ Alfons J.P. Smolders ${ }^{1,2}$
}

\author{
${ }^{1}$ B-WARE Research Centre, Radboud \\ University Nijmegen, Nijmegen, The \\ Netherlands \\ ${ }^{2}$ Institute of Water and Wetland Research, \\ Radboud University, Nijmegen, The \\ Netherlands \\ ${ }^{3}$ Nature Conservation and Plant Ecology \\ Group, Wageningen UR, Wageningen, The \\ Netherlands \\ ${ }^{4}$ Soil Physics and Land Management Group, \\ Wageningen UR, Wageningen, The \\ Netherlands \\ ${ }^{5}$ Soil Geography and Landscapes Group, \\ Wageningen UR, Wageningen, The \\ Netherlands

\section{Correspondence} \\ Gijs van Dijk, Institute of Water and Wetland \\ Research, Radboud University, B-WARE \\ Research Centre, Radboud University \\ Nijmegen, P.O. Box 6558, 6503 GB Nijmegen, \\ The Netherlands. \\ Email: g.vandijk@b-ware.eu
}

\begin{abstract}
In coastal zones globally, salinization is rapidly taking place due to the combined effects of sea level rise, land subsidence, altered hydrology, and climate change. Although increased salinity levels are known to have a great impact on both biogeochemical and hydrological processes in aquatic sediments, only few studies have included both types of processes and their potential interactions. In the present paper, we used a controlled 3-year experimental mesocosm approach to test salinity induced interactions and discuss mechanisms explaining the observed hydrological changes. Surface water salinity was experimentally increased from 14 to $140 \mathrm{mmol}$ $\mathrm{Cl}$ per L (0.9 and 9 PSU) by adding sea salt which increased pore water salinity but also increased sulfate reduction rates, leading to higher sulfide, and lower methane concentrations. By analyzing slug test data with different slug test analysis methods, we were able to show that hydraulic conductivity of the hyporheic zone increased 2.8 times by salinization. Based on our hydrological and biogeochemical measurements, we conclude that the combination of pore dilation and decreased methane production rates were major controls on the observed increase in hydraulic conductivity. The slug test analysis method comparison allowed to conclude that the adjusted Bouwer and Rice method results in the most reliable estimate of the hydraulic conductivity for hyporheic zones. Our work shows that both physical and biogeochemical processes are vital to explain and predict hydrological changes related to the salinization of hyporheic zones in coastal wetlands and provides a robust methodological approach for doing so.
\end{abstract}

\section{KEYWORDS}

downward seepage, hydraulic conductivity, methane, methanogenesis, pore dilation, salinization

\section{I INTRODUCTION}

Climate change, sea level rise, and extensive land use change have resulted in an increasing occurrence of salinization of surface waters (Abarca \& Post, 2010; Herbert et al., 2015) and increased saline groundwater intrusion in coastal zones (i.e., Oude Essink, Van Baaren, \& De Louw, 2010; Rengasamy, 2006; Velstra, Groen, \& De Jong, 2011; Werner \& Simmons 2009). This not only affects agricultural land use (Katerji, Van Hoorn, Hamdy, \& Mastrorilli, 2003; Rengasamy, 2010) but also threatens groundwater resources used for drinking water abstraction, and the ecological functioning of natural freshwater wetlands due to large biogeochemical consequences of salinization (e.g., Bonte \& Zwolsman, 2010; Herbert et al., 2015; Lamers, Smolders, \& Roelofs, 2002a; Oude Essink \& Kooi, 2011; Pitman \& Lauchli, 2002).
In addition, anthropogenically lowered surface water levels and groundwater levels have resulted in increased land subsidence rates, especially in areas with peaty soils such as densely populated deltaic areas. The western part of the Netherlands is an example of a coastal wetland prone to both salinization and land subsidence, with regions showing more than four meters of subsidence during the last millennium, large parts of which are now situated below mean sea level (Nieuwenhuis \& Schokking, 1997; Schothorst, 1977). Although these low areas are generally protected against flooding by the construction of dikes and the implementation of complex water management systems, protection against salinization due to upwelling of brackish or saline groundwater or a shortage of freshwater supply, especially during dry summers also needs to be implemented (De Louw et al., 2011; Oude Essink et al., 2010; Velstra et al., 2011). 
Water management in these areas needs to consider that increased salinity has a strong effect on soil and water biogeochemistry as a result of the increase in ions such as chloride (Cl), sodium, magnesium, and calcium but also sulfate. Surface water salinization will primarily affect hydrological and biogeochemical processes in the hyporheic zone (here defined as the aquatic sediment, the interface between surface water and groundwater conform; Orghidan, 1959). The hyporheic zone is of special interest because it is a hotspot for biogeochemical processes and often harbors a large microbiological diversity and steep redox gradient (Boulton, Findlay, Marmonier, Stanley, \& Valett, 1998; Storey, Fulthorpe, \& Williams, 1999). Increased salinity in the sediment can have important biogeochemical and eco(hydro)logical consequences including direct effects on plant and animal communities (Nielsen et al., 2003; Remane \& Schlieper, 1958) including agricultural crops and cattle (Pitman \& Lauchli, 2002) but also changes in microbial communities and related biogeochemical cycling (e.g., Baldwin, Rees, Mitchell, Watson, \& Williams, 2006; Van Dijk et al., 2015; Weston, Dixon, \& Joye, 2006).

Indirectly, the increased water density due to increased surface water salinity may also have physical and hydrological consequences. However, only few studies focus on the effects of surface water salinization on hydrological and biogeochemical processes and their interactions in the hyporheic zone of coastal wetlands, especially long-term effects have yet to be analyzed. Laboratory studies showed that salinity may influence the hydraulic conductivity of soils (Mehnert \& Jennings, 1985) modifying the infiltration rate of saline water into soils and altering groundwater flow patterns. Most studies, however, deal with mineral soils, and little knowledge exists about the effects of salinity on the interaction between biogeochemical processes and the hydraulic conductivity of peat soils. Water flow through wetland sediments is affected by the hydraulic conductivity, which can vary greatly among different types of peat with varying degrees of decomposition (e.g., Boelter, 1969; Chason \& Siegel, 1986; Stofberg, Van Engelen, Witte, \& Van der Zee, 2016). Laboratory experiments and models (e.g., Comas \& Slater, 2004; Kettridge \& Binley, 2010; Ours, Siegel, \& Glaser, 1997) indicate that increased salinity can increase flocculation of particles such as humic acids in peat soils, causing pore dilation which potentially influences the hydraulic conductivity of peat soils. As a consequence of increased salinity, increased sulfate concentrations can enhance sulfate reduction in anaerobic sediments and suppress methanogenesis (Baldwin et al., 2006; Lamers et al., 2002b; Segers, 1998; Weston et al., 2006) that is known to influence hydraulic conductivity in peatlands (Baird \& Waldron, 2003). Although these studies indicate large effects of salinity on hydrology or biogeochemistry, the combined measurement of biogeochemical and hydrological processes in long term field studies is to our knowledge currently missing. In the present paper, the effects of increased salinity (140 mmol Cl per L [9 PSU]; brackish conditions) on biogeochemical processes and the hydraulic conductivity in the hyporheic zone were studied in a controlled field experiment in a Dutch coastal peatland. We hypothesized that interacting biogeochemical and hydrological processes increases the infiltration rate of saline water into the sediment under increased surface water salinity.

\section{2 | MATERIALS AND METHODS}

\section{1 | Site description}

The field experiment was carried out in a large permanent ditch (more details below) located in a freshwater coastal wetland (Ilperveld) located north of Amsterdam (the Netherlands). This semi-natural wetland is a nature reserve including large areas of open water connected via sluices and pumping stations to surrounding canals (e.g., Noordhollands Kanaal) with a strictly regulated surface water level of about $1.5 \mathrm{~m}$ below mean sea level. The wetland has been influenced by anthropogenic use since the Middle Ages. We selected the llperveld because it was affected by the infiltration of brackish surface water and several flooding events during the last centuries as a result of anthropogenic land subsidence. Since the 1930s, the influence of brackish water decreased and salinity levels dropped due to the construction of a large dam (Afsluitdijk) eliminating seawater influence (De Beaufort, 1954). The chemical sediment composition, however, is still indicative of the former brackish influence (increased $\mathrm{Cl}$, sodium, and sulphur [S] concentrations). The soil surface level of the area varies between 1.3 and $1.5 \mathrm{~m}$ below mean sea level ( -1.3 to $-1.5 \mathrm{~m})$. Directly adjacent to the study area, there are a number of deeper polders (agricultural lands that need active pumping to avoid flooding; surface level at -4 to $-5 \mathrm{~m}$ ).

The llperveld subsoil is characterized by a sequential stratification of peat and clay layers (Westland formation [Figure 1]). The toplayer consists of a $2 \mathrm{~m}$ thick peat deposit, situated on top of a $3 \mathrm{~m}$ thick layer of sequential stratification of peat and clay layers. These layers are underlain by a $30 \mathrm{~m}$ sandy aquifer (Formation of Twente) based on a sand layer rich in loam and silt (Formation of Drenthe; National Dino Database, TNO). The area is part of a large former Sphagnum bog that was formed between 2,500 and 1,500 years before present (Bakker \& Van Smeerdijk, 1982; Willemsen, Van't Veer, \& Van Geel, 1996; Witte \& Van Geel, 1985). The area has been strongly affected by anthropogenic influence (i.e., drainage, construction of ditches and canals, peat extraction, and the creation of deep polders), which had a major impact on its hydrological functioning. The current average phreatic groundwater level fluctuates around the average surface water level (-1.53 m NAP [below mean sea level]). The hydraulic head of the phreatic aquifer is at about $-2.5 \mathrm{~m}$ NAP in the southern and $-3 \mathrm{~m}$ NAP in the northern part (i.e., 0.97 and $1.47 \mathrm{~m}$ below surface water level, respectively). Despite strong land subsidence, the groundwater head of the phreatic layer is lower compared with the regional hydraulic head, indicating downward seepage of approximately $0.1 \mathrm{~mm} / \mathrm{d}$ based on hydrological modeling (Nelen \& Schuurmans Consultants, 2005).

The experiment was carried out in a dead-end canal $\left(52^{\circ}\right.$ $27.225 \mathrm{~N}-4^{\circ} 55.885 \mathrm{E}$ ) of about $250 \mathrm{~m}$ long and $10-15 \mathrm{~m}$ wide, with a water depth of $1.3 \mathrm{~m}$, surrounded by reedlands and agricultural peat meadows. The aquatic sediment was unvegetated and consisted of a $15 \mathrm{~cm}$ decomposed organic sludge layer on top of a $1.5 \mathrm{~m}$ thick layer of Sphagnum peat on clay (Figure 1). Both the sludge and the peat layer are rich in organic matter (75\% and $90 \%$ ). The bulk density of the peat ( $80 \mathrm{~g} \mathrm{DW}$ per L; $48 \mathrm{hr}$ at $70^{\circ} \mathrm{C}$ ) is higher compared with that of the sludge layer (60 g DW per L). 
(a)

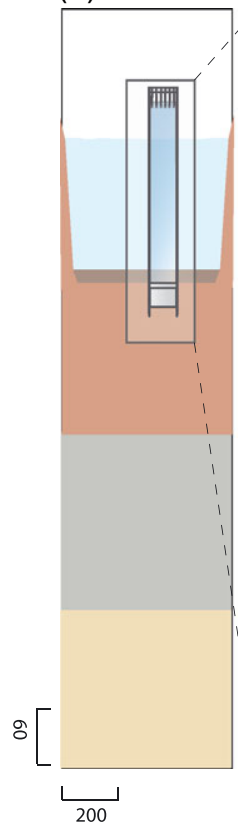

(b)

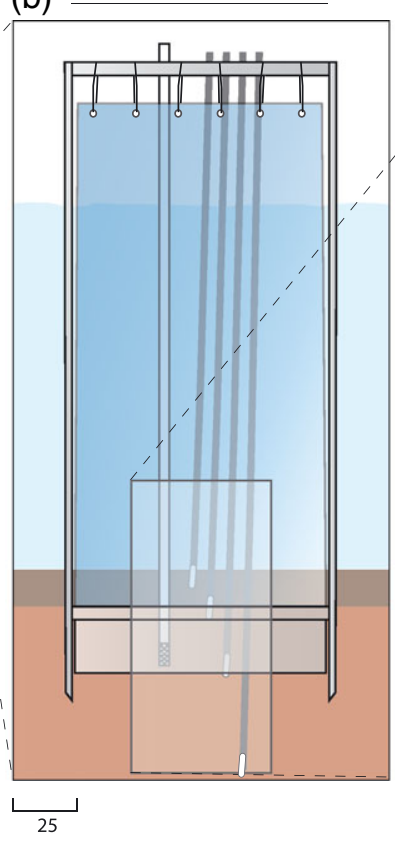

aquatic sediment

surface water (c)

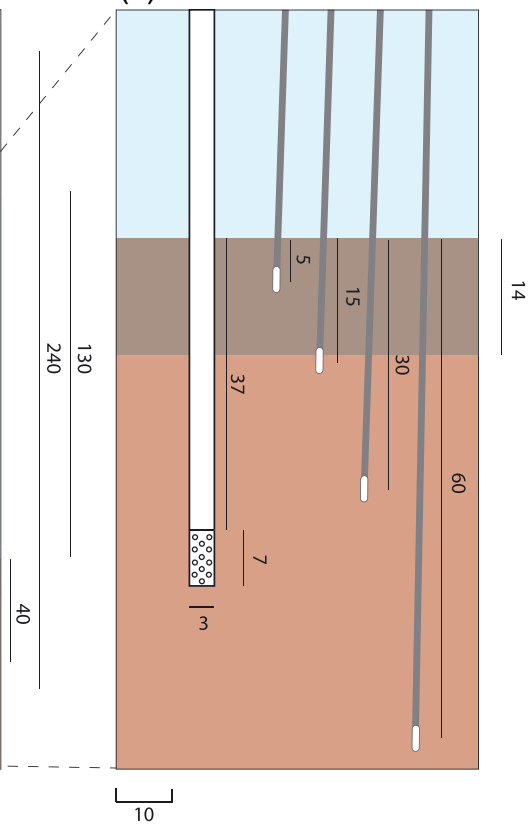

FIGURE 1 (a) Enclosure placed in the water column of a canal with peat soil on top of clay and sand. (b) Enclosure overview showing steel frame, flexible polyvinylchloride enclosure, and piezometer and ceramic cups. (c) Detailed overview of sampling methods, on the left (in white) the piezometer with filter at the bottom, on the right ceramic cups for pore water sampling at different depths. Scales in $\mathrm{cm}$

\section{2 | Experimental set-up}

\section{3 | Enclosure experiment}

To test the effect of salinity on hydraulic conductivity of the hyporheic zone, we placed 16 enclosures (diameter $95 \mathrm{~cm}$ ) in an unvegetated canal. To avoid canal-edge effects, we placed the enclosures in the middle of the canal, and randomly assigned an increased salinity $(n=4)$ and a control $(n=4)$ treatment (eight extra enclosures, with two intermediate salinity treatments were placed in which only chemical parameters and the enclosure volume were determined). The enclosures had stainless steel frames and flexible polyvinylchloride (PVC) foil ( $\approx 1 \mathrm{~mm}$ thick). Flexible PVC foil was used to reduce the effect of the enclosure itself and to assure the effect of waves, wind, and mixing were not fully excluded, which would have been the case with fixed sides. The top of the open PVC enclosures was connected to the steel frame by rubber bands, keeping the upper part $30 \mathrm{~cm}$ above the water surface (Figure 1). At the bottom the enclosures were fastened to a steel ring (30 cm length), placed at $40 \mathrm{~cm}$ below the sediment-water interface. In this way, miniature ponds with flexible volumes were created, in which interactions between the atmosphere (precipitation and evaporation) and the enclosed surface water remained intact. Vertical exchange of water between the surface water, the hyporheic zone, underlying sediments, and groundwater also remained intact (Figure 1). Lateral flow of the surface water was eliminated, while lateral pore water flow (up to the installation depth of $40 \mathrm{~cm}$ beneath the sediment-water interface) was strongly reduced inside the enclosure. During the experimental period enclosures of both the control and the increased salinity treatment must nevertheless have lost water via the aquatic sediment underneath the steel ring due to the average precipitation surplus of about $300 \mathrm{~mm} /$ year (30 yearrs average, Sluijter, Leenaers, \& Camarasa, 2011, recent years KNMI, 2015) at the study location and an equal surface water level inside and outside the enclosures (visual observations).

\subsection{Salinity treatment}

In four enclosures, the surface water salinity was increased from the ambient canal condition of $14 \mathrm{mmol} / \mathrm{L} \mathrm{Cl}$ (0.9 PSU, low salinity, and control treatment), to $140 \mathrm{mmol} / \mathrm{L} \mathrm{Cl}$, (9 PSU increased salinity treatment), by adding artificial sea salt (Tropic Marin $\left.{ }^{\circledR}\right)$. The $140 \mathrm{mmol} / \mathrm{L}$ treatment was selected as a realistic salinity level for future salinization in Dutch coastal wetlands. To keep salinity as constant as possible, and to avoid dilution by rainwater, sea salt was added periodically during the experimental period when surface water salinity levels dropped to values that were $10 \%$ lower than the target values; pore water salinity however remained stable.

\section{5 | Hydrological measurements}

Surface water volumes of the flexible enclosures were measured the start and end of the experiment ( August 12, 2010 to July 30, 2013, total duration of 35 months). The volume of the enclosures was calculated based on measurements of enclosure diameter at the surface water level (R1 in Figure 2), based on the volume of a two-truncated cone (Equation 1) and assuming that the middle of the flexible bag had the smallest diameter. Based on the difference between enclosure diameter (at the surface water level) and the diameter of the steel frame at the top, the angle of the cones was calculated. The volume 


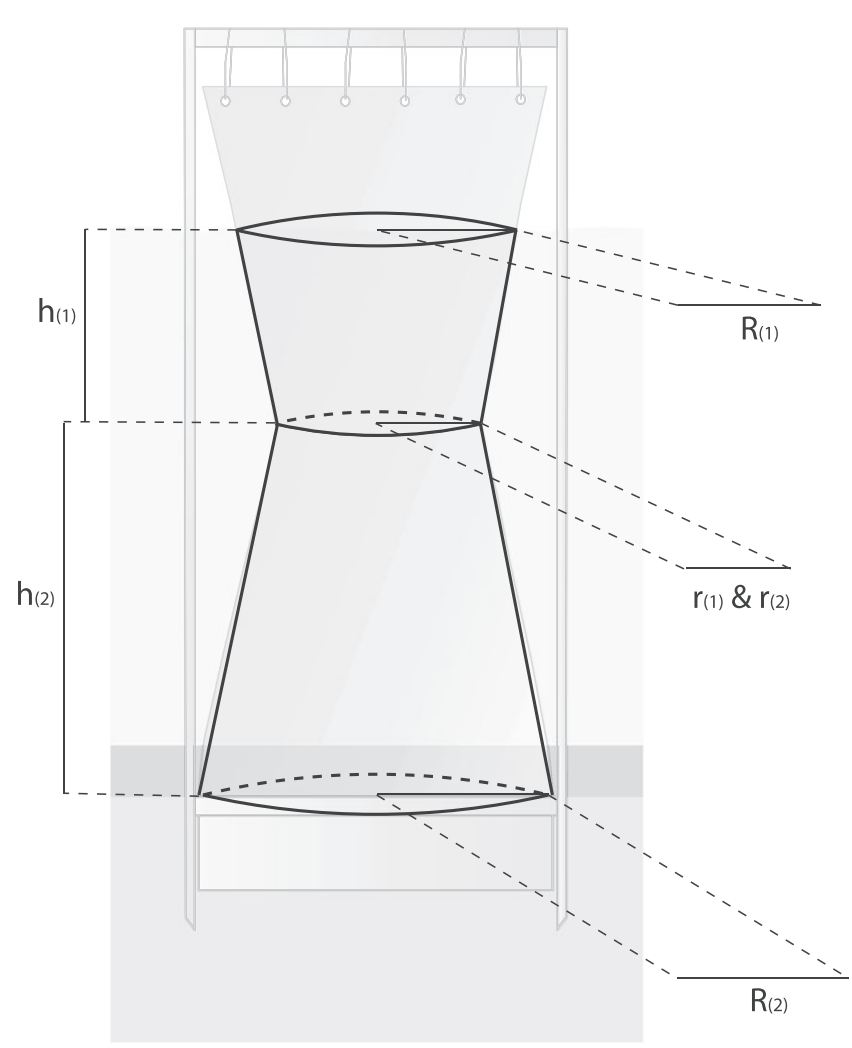

FIGURE 2 A schematic illustration of how the enclosure volume was calculated, for calculating the content of different parts of two cones

of the enclosures was calculated by summing the volume of two truncated cones, using Equation 1 and Figure 2.

$$
V=\frac{1}{3} \pi h\left(R^{2}+R r+r^{2}\right)
$$

To measure the in situ effect of salinity on the saturated horizontal hydraulic conductivity $\left(K_{s}\right)$, slug tests were used, after placement of piezometers, to quantify $\mathrm{K}_{\mathrm{s}}$ in the hyporheic zone (Ong \& Zlotnik, 2011).

The bottom-end of the piezometers was closed water-tight with a cap, and the perforated section was covered with nylon cloth to prevent clogging of the filter. Time series of water pressure (frequency $2 \mathrm{~s}^{-1}$ ) were obtained using divers (TD Divers DI240, Van Essen Instruments), which were placed in the piezometers. The piezometers consisted of cylindrical PVC tubes (outer diameter $31 \mathrm{~mm}$ ), with the filter $(70 \mathrm{~mm})$ located in the denser Sphagnum-dominated peat layer at a depth of $35-42 \mathrm{~cm}$ below the surface water-aquatic sediment boundary (Figure 1). The filter was constructed by drilling holes (diameter $0.7 \mathrm{~mm}, 84 \%$ perforation of total filter surface) in the piezometer (Figure 1).

In slug tests, a known volume of water is rapidly poured into a piezometer, which induces a stepwise increase in water pressure which then decreases over time from which the saturated hydraulic conductivity was calculated. Piezometers were installed in both the control and the salinity treatment enclosures (one per enclosure). Typically, piezometers or wells are "developed", a procedure where drilling debris is removed from the piezometer intake (Baird, Surridge,
\& Money, 2004; Kill, 1990; Butler, 1998). Because of the fragile nature of hyporheic zone and peat sediments, we decided to not develop the piezometers, as it involves inducing strong flows, which may alter the pore architecture. After the water level in the piezometers stabilized, a slug of $100 \mathrm{ml}$ water of a salinity similar to the local surface water was added. To verify the quality and reproducibility of the slug tests, three replicate tests were taken per piezometer. Due to technical errors in two of the divers the hydraulic conductivity could only be calculated using three replicates, whereas enclosure volume and chemical depth profiles were calculated using four replicates for each treatment.

\subsection{Comparison of slug test analyses}

Various approaches have been described in literature to calculate $K_{s}$ (saturated hydraulic conductivity) using slug test data (e.g., Bouwer \& Rice, 1976; Cooper, Bredehoeft, \& Papadopulos, 1967; Hvorslev, 1951; Hyder, Butler, McElwee, \& Liu, 1994; van Beers, 1983), all assuming a homogeneous aquifer with uniform thickness. The hydrostatic time lag method developed by Hvorslev (1951) has frequently been employed in wetland studies (Baird, Eades, \& Surridge, 2008; Baird et al., 2004; Surridge, Baird, \& Heathwaite, 2005; Whittington $\&$ Price, 2006). Three additional assumptions for this method are that (a) the filter vertically stretches the whole aquifer (i.e., fully penetrating piezometer), (b) the aquifer is confined (it remains saturated), and (c) water storage change is negligible (steady state flow).

The approach developed by Bouwer and Rice (1976; BR) is suitable for both confined and phreatic unconfined aquifers, and for partially penetrating piezometers (Bouwer, 1989). Briefly, the BR method is based on the Thiem equation of steady state flow to or from a piezometer (Bouwer \& Rice, 1976; Thiem, 1906) (Equation 2):

$$
\mathrm{Q}(\mathrm{t})=2 \pi \mathrm{K}_{\mathrm{s}} \mathrm{L} \frac{\mathrm{h}(\mathrm{t})}{\mathrm{F}}
$$

where $Q(t)$ is flow rate, $L$ is the filter length, $h(t)$ is the increase in water level in the piezometer relative to the initial groundwater level, and $F$ is a shape factor correcting for the piezometer geometry. Bouwer and Rice (1976) empirically developed equations to derive $F$ from the piezometer radius, position of the filter below the groundwater table, and estimated aquifer thickness. The performance of these empirical equations for many realistic field applications (requiring relatively small filter length as compared with filter diameter) is, however, limited (Brown, Narasimhan, \& Demir, 1995; Hyder \& Butler, 1995; Zlotnik, Goss, \& Duffield, 2010). More recently, (Zlotnik et al., 2010) established a general, analytical closed-form expression of the BR shape factor $\left(F_{Z G D}\right)$ to account for piezometer geometry (Equation 3 ).

$$
F_{Z G D}=\left(\sum_{i=1}^{\infty}\left\{\left(\cos \left(\beta_{i} \frac{H}{D}\right)-\cos \left(\beta_{i} \frac{H-L}{D}\right)\right)^{2} \times \frac{K_{0}\left(\frac{\beta_{i} r_{w}^{*}}{D}\right)}{\beta_{i}^{3} K_{1}\left(\frac{\beta_{i} r_{w}^{*}}{D}\right)}\right\}\right) / \frac{L r_{w}^{*}}{2 D^{2}}
$$

Here, $K_{0}$ and $K_{1}$ are the modified Bessel functions of third kind and zeroth or first order and $\beta_{i}=\pi(i-0.5) . r_{w}^{*}$ represents the piezometer radius scaled by the anisotropy coefficient (Equation 4$)$. 


$$
r_{w}^{*}=\frac{r_{w}}{\sqrt{K_{h} / K_{v}}}
$$

The coefficients $K_{h}$ and $K_{v}$ are the horizontal ( $h$ ) and vertical ( $v$ ) saturated hydraulic conductivity. We assumed the peat sediment had an anisotropy ratio of one. See Zlotnik et al. (2010) for details on the derivation and Nijp (2015) for the calculation of $F_{Z G D}$ using the R software ( $R$ Core Team, 2014). The only remaining assumption is that the storativity is negligible. Following recommendations by Butler (1998) to minimize the effects of compression on the calculation of $\mathrm{K}_{\mathrm{s}}$, we selected a normalized head range of $0.2-0.3$. The quality of the $\mathrm{K}_{\mathrm{s}}$ estimates was assessed by comparing observed and simulated water pressures using Willmott's modified index of agreement (Legates et al., 2011; Willmott et al., 1985).

\section{7 | Chemical analyses}

Surface water samples and sediment pore water samples were taken in the period of June to August 2013. Sediment pore water samples were collected at 5, 15, 30, and $60 \mathrm{~cm}$ depth in the sediment with a vacuumed syringe connected to a ceramic cup via a Teflon tube. Pore water depth profiles were collected in the highest and lowest salinity treatment (the treatments where the slug tests took place); in the two intermediate salinity treatments, pore water samples were only collected at $10 \mathrm{~cm}$ depth. Extra sediment pore water samples were collected for pore water methane analyses by connecting vacuumed $12 \mathrm{ml}$ glass exetainers (Labco exetainer ${ }^{\circledR}$, High Wycimbe, UK) in which concentrations were measured in the headspace and recalculated for the water volume using Henry's constant.

For the analyses of $\mathrm{S}$, calcium, and magnesium inductively coupled plasma spectrophotometry (ICP-Optical Emission Spectrometer, Thermo Scientific iCAP 6000 Series ICP) was used. Prior to elemental analyses, $10 \mathrm{ml}$ of each sample was stored at $4^{\circ} \mathrm{C}$ until analyses with $0.1 \mathrm{ml}(65 \%) \mathrm{HNO}_{3}$ to prevent metal precipitation. To determine sodium and $\mathrm{Cl}$ concentrations, $20 \mathrm{ml}$ of each sample was stored at $-20^{\circ} \mathrm{C}$ and analyzed colorimetrically with an Auto Analyzer 3 system (Bran and Luebbe). Sodium and potassium were determined with a Technicon Flame Photometer IV Control (Technicon Corporation). $\mathrm{CH}_{4}$ concentrations were measured with a Hewlett-Packard 5890 gas chromatograph (Avondale, California) equipped with a flameionization detector and a Porapak Q column (80/100 mesh) operated at $120^{\circ} \mathrm{C}$ with $\mathrm{N}_{2}$ as carrier gas. Sulfide concentrations were determined directly after sampling by fixing $10.5 \mathrm{ml}$ pore water with $10.5 \mathrm{ml}$ Sulfide Anti Oxidant Buffer, and using an Orion sulfideelectrode and a Consort Ion meter (type C830) for analyses (Van Gemerden, 1984).

\section{8 | Data analysis}

The differences in enclosure volume between the control and salinity treatment was tested with a one-way analysis of variance (ANOVA). We tested for normality and homogeneity of variances using the Shapiro-Wilk test and Levene's test, no transformations were applied to the data. Differences in pore water element concentrations over depth were assessed using a generalized linear mixed model, using salinity treatment and depth as fixed factor and time as repeated factor; the co-variance type used was AR(1) Heterogeneous. A Least Significant Difference post-hoc test was used to test for statistically significant differences. Differences in hydraulic conductivity $\left(K_{s}\right)$ between salinity treatments were assessed with a two-way ANOVA with salinity treatment and slug test analysis method as fixed factors, and enclosure as within-subjects factor. The three replicated slug tests per enclosure yielded very similar $K_{s}$ estimates (median deviation from mean per enclosure was $3 \%$ ), indicating that the reproducibility of slug tests is high and no well development was required. This was supported by a repeated measure ANOVA with slug test analysis method and salinity treatment as fixed factors and repetition as within-subjects factor, showing that $\mathrm{K}_{\mathrm{s}}$ did not significantly differ at different points in time $(p>0.2)$. We therefore removed the factor time from our analysis. Data were normally distributed (Shapiro-Wilk test; $p>0.07$ ), but the assumption of homogeneous variances among treatment-method groups was not met $(p=0.001)$. To account for this violation, we calculated robust standard errors using a robust parameter estimate covariance matrix in the Generalized Linear Model procedure (White, 1980). All tests were carried out using SPSS Statistics for Windows (Version 21.0. IBM Corp. Armonk, NY, 2012).

\section{3 | RESULTS}

\section{1 | Salinity effects on hydrology}

During the start of the experiment the water volume of the flexible enclosures was around 1,050 L and did not differ between both salinity treatments ( $p=0.55$ ) (Figure 3a). After 3 years however, the water volume in the enclosures with increased salinity had decreased by $61 \%$ ( $p$ < 0.001) (Figure 3a). The enclosure volume measured after two experimental years decreases logarithmically as function of salinity $\left(R^{2}=0.99\right.$; Figure $\left.3 b\right)$. An opposite relation was found between enclosure volume and pore water methane concentrations $\left(R^{2}=0.99\right.$; Figure 3c). Two intermediate salinity treatments are presented in Figure 3, which are not further discussed in the present paper as other hydrological measurements (slug tests) were only done in the 14 and $140 \mathrm{mmol} \mathrm{Cl}$ per L treatments.

The average hydraulic conductivity $\left(\mathrm{K}_{\mathrm{s}}\right)$ of the aquatic peat sediment was on average 2.8 times higher $(p<0.01)$ in enclosures with increased surface water salinity (Figure 4). This increase appeared not to be affected by the method used to calculate $K_{s}$, all methods fitted the data well (in $95 \%$ of all $K_{s}$ estimates, the Willmott index of agreement between observed and modeled hydraulic head exceeded 0.94), but showed a significant effect of salinity. Compared with the BR method with Zlotnik shape factor $\left(F_{Z G D}\right)$, however, the Hvorslev method yielded conductivity estimates which were $24 \%$ larger $K_{s}$ ( $p=0.25$ ); and the BR method (without $\mathrm{F}_{\mathrm{ZGD}}$ ) yielded a $28 \%$ lower $\mathrm{K}_{\mathrm{s}}$ $(p=0.08)$ (see Figure 4).

\section{2 | Effects of surface water salinization on sediment biogeochemistry}

Increased surface water salinity had a significant impact on chemical composition and biogeochemical processes in the aquatic 

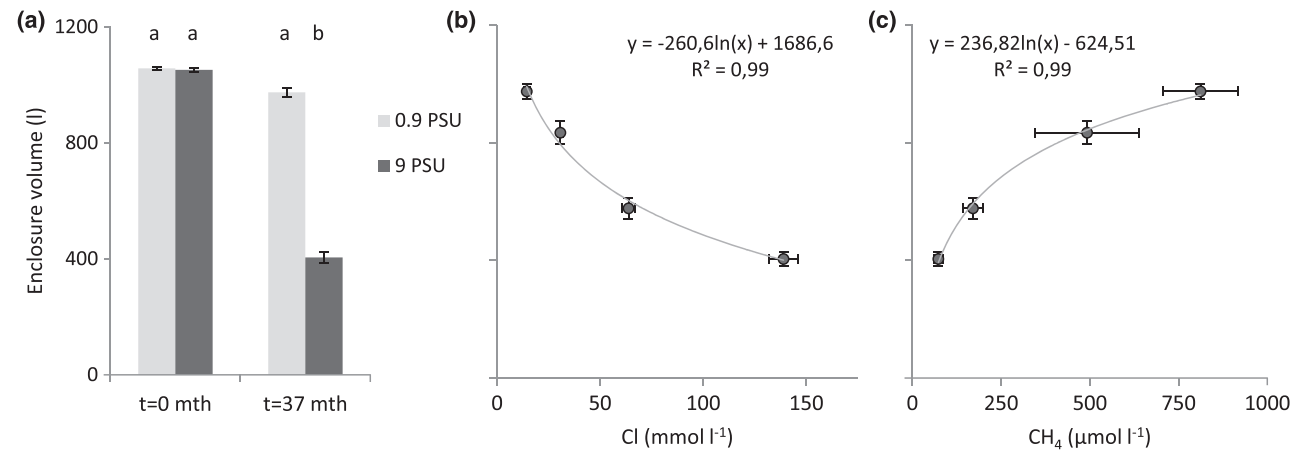

FIGURE 3 (a) The average water volume at the start of the experiment ( $t=0$ months) and after 3 years ( $t=37$ months) for the control treatment (0.9 PSU, $14 \mathrm{mmol} / \mathrm{L} \mathrm{Cl}$ ) and increased salinity treatment (9 PSU, $140 \mathrm{mmol} / \mathrm{L} \mathrm{Cl}$ ), (+/- S.E.M., [ $n=4])$. (b) and (c) the average final enclosure volume (error bars represent +/- S.E.M., $[n=4]$ ) for both salinity treatments and for two additional intermediate salinity treatments $(31$ and $64 \mathrm{mmol} / \mathrm{L} \mathrm{Cl})$ plotted against the pore water chloride concentration and the pore water methane concentration respectively

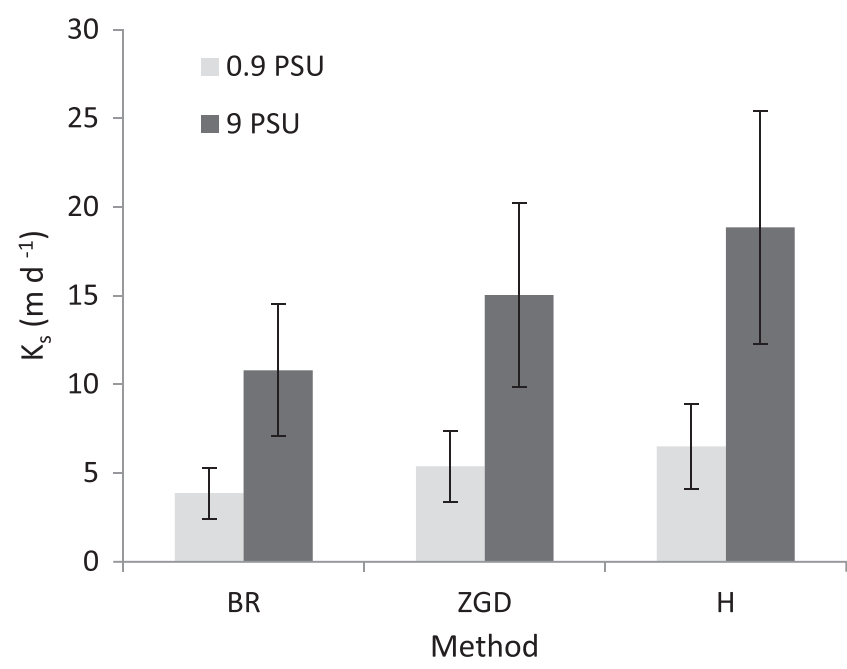

FIGURE 4 Effect of salinity treatment (colors) in slug test on average saturated hydraulic conductivity $\mathrm{K}_{\mathrm{s}}$ for three analysis methods; $\mathrm{H}=$ Hvorslev (Hvorslev, 1951), BR = Bouwer-Rice (Bouwer \& Rice, 1976), ZGD = Bouwer-Rice with shape factor conform Zlotnik et al. (2010), (error bars represent +/- S.E.M., [ $n=3]$ ) sediment. $\mathrm{Cl}$ concentrations not only increased significantly $(p<0.005)$ up to the treatment level in the top layer but also deeper in the sediment, up to $30 \mathrm{mmol} / \mathrm{L} \mathrm{Cl}, 20 \%$ of the treatment level (Figure 5). After 2.5 to 3 years of surface water salinization the pore water $\mathrm{Cl}$ concentration in the salinity treatment was increased to the treatment level up to a depth of $15 \mathrm{~cm}$ and was still significantly increased $(p=0.004)$ at a depth of $60 \mathrm{~cm}$. Similar patterns were found for cations (Sodium, Magnesium, Calcium, Potassium; data not shown). Pore water $\mathrm{Cl}$ concentrations in the control treatments remained around $12 \mathrm{mmol} / \mathrm{L}$ in the depth profile and even showed a minor decrease in the upper 5 and $15 \mathrm{~cm}$. In the high salinity treatment, both pore water total $\mathrm{S}$ concentration as well as sulfide concentration were increased (at a depth of 5 to $10 \mathrm{~cm}$ from about 0.4 to $5.0 \mathrm{mmol} / \mathrm{L}(p=0.003)$ for total $\mathrm{S}$ and from 0.13 to $4.9 \mathrm{mmol} / \mathrm{L}(p=0.01)$ for sulfide (Figure 5$)$. In contrast, pore water methane $\left(\mathrm{CH}_{4}\right)$ concentrations were strongly decreased (from 0.8 to $0.047 \mathrm{mmol} \mathrm{CH}_{4}$ per $\mathrm{L}$, >90\% decrease in the top layer) up to a depth of at least $30 \mathrm{~cm}$ in the salinity treatment $(p<0.005)$ (Figure 5). Pore water depth profiles were not collected in the two intermediate salinity treatments; pore water
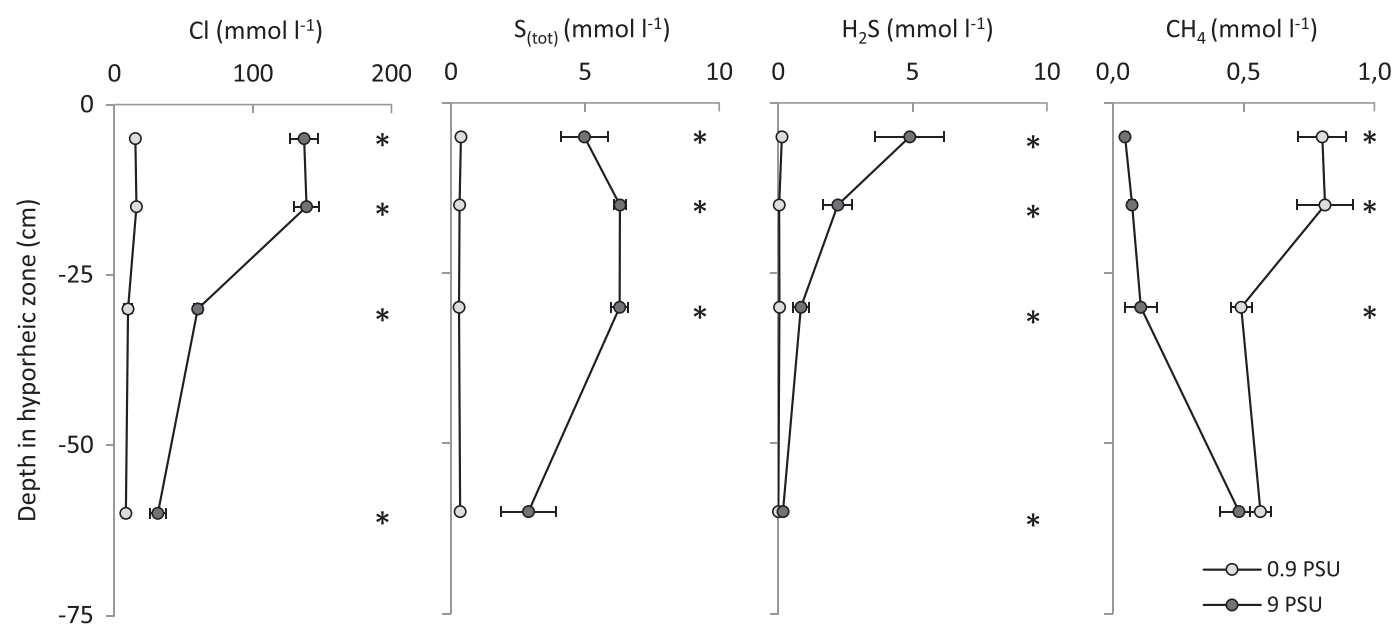

FIGURE 5 Depth profiles for pore water concentrations in the aquatic sediment (a) chloride, (b) total sulphur, (c) sulfide, and (d) methane in mmol/ $\mathrm{L}$, for control treatment (0) and $140 \mathrm{mmol} \mathrm{Cl}$ per $\mathrm{L}$ salinity treatments $(\bullet) 37$ months after the start of the experiment. * $p<0.05$; note different scales for the $x$-axes, (error bars represent + /- S.E.M., $[n=4]$ ) 
samples at $10 \mathrm{~cm}$ depth were analyzed and showed intermediate effects and are therefore not discussed in more detail.

\section{4 | DISCUSSION}

\section{1 | Possible mechanisms explaining increased hydraulic conductivity due to salinization}

The striking negative correlation between salinity and change of enclosure volume through time presented in this study was unexpected. The decreased volume of the flexible enclosure as a result of increased surface water salinization can be caused by several processes.

First, increased salinity may increase water density and might thereby enhance vertical (downward) water flow (Holzbecher, 1998). In the present study, the water density increased from $1000.646 \mathrm{~kg} / \mathrm{m}^{3}$ in the control treatment to $1007.735 \mathrm{~kg} / \mathrm{m}^{3}$ in the highest salinity treatment. Based on Darcy's Law this would lead to a $0.7 \%$ increase in vertical water flux (assuming similar viscosity, temperature of $20^{\circ} \mathrm{C}$ and permeability, but different water density for the control and increased salinity treatment). As we found that the increased salinity treatment induced an $83 \%$ increase in hydraulic conductivity (Figure 4), the contribution of increased water density to the observed enhanced vertical water flow can only be marginal.

Second, increased surface water salinity may influence the evaporative water losses from the surface water. Increased salinity would, however, have decreased evaporation rates due to increased attraction of solvent molecules in the water (Salhotra, Adams, \& Harleman, 1985).

Thirdly, a physical explanation of increased hydraulic conductivity in peat soils with increased salinity could be the process of pore dilation. Dilation of macro pore spaces is caused by the flocculation of the organic acids located on the surfaces of peat fibers as a result of an increased salinity. By modifying the pore water chemistry, increased salinity alters the physical properties of the sediment and can influence the hydraulic conductivity in peat soils (Hoag \& Price, 1997; Ours et al., 1997). The effect of pore dilation on $K_{s}$ was further studied by Comas and Slater (2004), who established a quantitative relation between the electric conductivity $(E C)$ and $K_{s}$ for peat soils $\left(K_{s} \propto E C^{n}\right.$, with $n$ varying from 0.25-0.30). Based on Comas and Slater (2004), we estimated the maximum contribution of pore dilation to the observed salinity induced changes in $\mathrm{K}_{\mathrm{s}}$ using Equation 5.

$$
K_{s}=K_{0}[E C]^{0.3}
$$

Here, $K_{0}$ represents the $K_{s}$ at an EC of $1 \mathrm{~S} / \mathrm{m}$, which was estimated from the average $\mathrm{K}_{\mathrm{s}}$ and $\mathrm{EC}$ in the control treatment. Following this formulation, the contribution of pore dilation on the $\mathrm{K}_{\mathrm{s}}$ due to increased EC (in the present study an increase in EC from $0.19 \mathrm{~S} / \mathrm{m}$ to $1.84 \mathrm{~S} / \mathrm{m}$ ) was estimated to cause a $97.6 \%$ increase in the high salinity treatment relative to the control treatment (factor 1.98). The relative increase in $\mathrm{K}_{\mathrm{s}}$ found in the present study in the high salinity treatment relative to the control treatment is however $179.2 \%$ (a factor 2.97). This indicates that, even though pore dilation alone can explain a substantial part of the $\mathrm{K}_{\mathrm{s}}$ increase, $82 \%$ of the increase in $\mathrm{K}_{\mathrm{s}}$ found in the present study remains unexplained. This large unexplained part of the increase in $\mathrm{K}_{\mathrm{s}}$ suggests that other mechanisms could also play an important role.

Fourthly, biogeochemical processes may have influenced the hydraulic conductivity $\left(K_{s}\right)$ in the hyporheic zone. Surface water salinization was shown to have a large impact on sediment biogeochemistry in the present study (Figure 5), not only leading to an increase of $\mathrm{Cl}$ and sodium but also to an increase of $\mathrm{S}$ concentrations (Weston et al., 2006, Van Dijk et al., 2015, Herbert et al., 2015). These increased S concentrations increase sulfate reduction rates, as shown by the strong increase in pore water sulfide concentrations (Figure 5). As demonstrated in several previous studies (Barlett, Bartlett, Hariss, \& Sebacher, 1987, Denier van der Gon \& Neue, 1995, Lamers et al., 2002b, Baldwin et al., 2006), increased sulfate concentrations in anaerobic, organic matter rich conditions result in increased sulfate reduction and increased sulfide concentrations. Compared with $\mathrm{Cl}$ (which can be used as an inert tracer), the total $\mathrm{S}$ concentration shows a less strong increase in the top of the sediment of the increased salinity treatment. The missing part of the total $S$ concentration in the pore water must have been transformed to sulfide by the sulfate reducing microorganisms, indicated by increased sulfide concentrations in the top layer (Figure 5). The sulfide produced is released to the water layer or atmosphere or bound to iron as $\mathrm{FeS}_{\mathrm{x}}$ in the sediment. Increased salinity significantly decreased pore water methane concentrations (94-78\% decrease in the top $30 \mathrm{~cm}$ of the aquatic sediment), also indicated in the correlation in Figure 3 and 5, showing a negative correlation between pore water $\mathrm{Cl}$ and methane concentrations $\left(\mathrm{R}^{2}=0.93\right)$. This can be explained by the direct effect of increased sulfate availability on methanogenesis. Thermodynamically, sulfate reduction is a more favorable process than methanogenesis (Segers, 1998). Sulfate-reducing bacteria therefore outcompete methanogens for access to organic substrates, which suppresses methanogenic activity when sufficient sulfate is present (Lamers, Farhoush, Van Groenendael, \& Roelofs, 1999, Smolders, Tomassen, Lamers, Lomans, \& Roelofs, 2002). Additionally, methanogenic activity may also be hampered due to physiological (osmotic) salt stress (only on the short term; Chambers, Reddy, \& Osborne, 2011) or sulfide toxicity (Cappenberg, 1975), reducing the methane production even further.

Decreased methanogenesis and consequential lower pore water methane $\left(\mathrm{CH}_{4}\right)$ concentrations decrease the formation of $\mathrm{CH}_{4}$ gas bubbles. Due to the very low solubility of methane in sediment pore water, accumulation and resulting oversaturation of $\mathrm{CH}_{4}$ likely resulted in the formation of $\mathrm{CH}_{4}$ gas bubbles in the pores of anaerobic peat soils including aquatic sediments. Methane gas bubbles are known to produce an upward pressure in the pore water of peat soils, which in combination with air pressure variations may lead to $\mathrm{CH}_{4}$ ebullition (Kellner, Price, \& Waddington, 2004, Kellner, Baird, Oosterwoud, Harrison, \& Waddington, 2006, Kettridge, Kellner, Price, \& Waddington, 2012). Upward moving $\mathrm{CH}_{4}$ gas bubbles can get stuck in the dense structure of peat soils (i.e., Kellner et al., 2004), such as Sphagnum peat in our case and thereby reduce water movement. Increased occurrence of $\mathrm{CH}_{4}$ gas bubbles and $\mathrm{CH}_{4}$ ebullition can therefore decrease the hydraulic conductivity of organic rich sediments such as the hyporheic zone in the control treatment of the present study (Baird \& Gaffney, 1995; Baird \& Waldron, 2003; Reynolds, Brown, Mathur, \& Overend, 
1992; Strack, Kellner, \& Waddington, 2005). Literature reports large decreases in the hydraulic conductivity of peat soils as a consequence of increased gas bubble content; Baird and Waldron (2003) report a decrease by a factor two, while Reynolds et al. (1992) found a decrease by a factor four. Although the hydraulic conductivity in peat soils can vary greatly due to large variations in peat quality, bulk density, and rate of decomposition (e.g., Boelter, 1969; Chason \& Siegel, 1986; Stofberg et al., 2016), gas bubbles may affect the hydraulic conductivity in a wide range of peat soils.

Apart from methane, other gas bubbles (sulfide, nitrogen gas, and entrapped air) can also influence the hydraulic conductivity modifying groundwater flow (Beckwith \& Baird, 2001; Marinas, Roy, \& Smith, 2013). Increased nitrogen gas content is, however, not expected in the present study. As sulfide is more soluble than methane gas (solubility of sulfide: 0.46 grams of gas dissolved in $100 \mathrm{~g}$ of water, solubility of methane: $0.0026 \mathrm{~g}$ of gas per $100 \mathrm{~g}$ of water, both at $15^{\circ} \mathrm{C}$ when the total pressure above the solution is $1 \mathrm{~atm}$. (Gevantman, 1999)), the effect of the increased sulfide concentration is expected to be lower. Field observations (Gijs van Dijk) indicate that almost no ebullition occurs in the high salinity treatments whereas much ebullition was observed in the control enclosures, which underlines that the increase in sulfide does not lead to increased ebullition.

In the increased salinity treatments the strong decrease (by 78-94\%) of pore water methane concentrations will therefore very likely have enhanced hydraulic conductivity. Additionally, at the start of the experiment, the increase in salinity may also have decreased the solubility of $\mathrm{CH}_{4}$ in the pore water (Yamamoto, Alcauskas, \& Crozier, 1976), thereby enhancing the formation of $\mathrm{CH}_{4}$ gas bubbles and stimulating $\mathrm{CH}_{4}$ ebullition. In combination with the formation of larger pores (pore dilation) and the reduced production of methane this may have led to an accelerated loss of $\mathrm{CH}_{4}$ enhancing hydraulic conductivity, also indicated by the strong relation between pore water methane concentration and the enclosure volume $\left(R^{2}=0.99\right.$, Figure $\left.3 c\right)$.

\subsection{Effect of slug test analysis methods on the hydraulic conductivity estimates}

Repeated measurements per location yielded very reproducible estimates of the hydraulic conductivity (median deviation among three replicates per location was $3 \%$ ). The hydraulic conductivity estimates in this study are in the range of other $K_{s}$ values for moderately decomposed Sphagnum peat, generally between about 0.01 and 50 m/d (Baird et al., 2008; Nijp, 2015; Surridge et al., 2005; Whittington \& Price, 2006). The increased salinity treatment values are in the higher end of the hydraulic conductivity range observed for comparable peats. However, different methods used to analyze slug test data generated different hydraulic conductivity estimates.

Typically, the interest of eco(hydro)logists lies in hyporheic zone or in the unconfined (i.e., rainwaterfed) aquifer, as this is the zone with most ecological and biogeochemical activity. A filter fully penetrating an aquifer or placed in the center of an aquifer, an assumption for the Hvorslev (1951) method, is often less relevant and less practical. In addition, the performance of the Bouwer and Rice (1976) approach may be limited for many realistic field applications, as the empirically developed equations for the shape factor are relatively inaccurate for piezometers with a small filter length relative to the filter diameter (Brown et al., 1995; Hyder \& Butler, 1995; Zlotnik et al., 2010). More recently, Zlotnik et al. (2010) developed an analytical closed-form expression for the shape factor in the BR method. This general shape factor enables the analysis of slug tests with the full range of possible and more eco(hydro)logically relevant piezometer geometries and positioning within aquifers. In this study, not accounting for the specific positioning and partial penetration of piezometer filters by employing the Hvorslev method resulted in an overestimation of saturated hydraulic conductivity estimates of the hyporheic zone (in this study of about 23\%) as compared with the BR approach with the Zlotnik shape factor, which matches well with results by Hyder et al. (1994) and Nijp (2015). The application of the BR slug test analysis, in which the positioning and partial penetration of piezometers is accounted for with empirical equations (Bouwer \& Rice, 1976), resulted in an underestimation of $\mathrm{K}_{\mathrm{s}}$ of about $28.2 \%$ (as compared with the BR approach with the Zlotnik shape factor). Although differences among slug test analysis methods were not significantly different, likely due to small samples size $(n=3)$, we recommend to use the BR approach in combination with the general shape factor presented by Zlotnik et al. (2010) to estimate the hydraulic conductivity in the hyporheic zone.

\subsection{Consequences of salinization on the hydrology of coastal wetlands}

In this study, we show that increased salinity significantly increased the hydraulic conductivity in the hyporheic zone of a coastal wetland in a long term controlled field setup. It is important to include this strong salinity-induced increase in hydraulic conductivity, into account in hydrological model simulations related to salinization effects. Especially coastal wetlands and other anaerobic sediments rich in organic material with potential methanogenic activity, susceptible to future salinity changes, are sensitive to such changes.

Salinization of deeper aquifers and surrounding areas can have major biogeochemical, agricultural and ecological consequences, influencing the nutrient, carbon, and S cycle (Herbert et al., 2015; Van Dijk et al., 2015). In peat aquifers with net infiltration and high methanogenic activity, increased salinity in the hyporheic zone might on the long term result in a nonlinear positive feedback where water infiltration becomes increasingly enhanced by salinity-induced increased hydraulic conductivity. This might result in an increased net infiltration from coastal wetlands to underlying aquifers and surrounding areas or losses through preferential flow paths and saline hotspots similar to those observed by De Louw, Vandenbohede, Werner, and Oude Essink (2013) and De Louw, Oude Essink, Stuyfzand, and Van der Zee (2010) for other soil types, although, at present it is unknown if results found in the present study are also applicable on a situation with saline water intrusion via the aquifer. For the present study area, these processes will probably be small due to the presence of thick clay layers. Changes of the hydraulic conductivity in the hyporheic zone, being a hotspot for biogeochemical and microbiological processes, can have a major impact on nutrient, $\mathrm{S}$ and, carbon cycles and the organisms living in this zone. 


\section{5 | CONCLUSION}

Although an increase in salinity is known to increase the hydraulic conductivity of mineral soils (Frenkel, Goertzen, \& Rhoades, 1977; Mandal et al., 2008; McNeal, 1967; Singh, Singh, Tiwari, \& Dwivedi, 2011; Zhu, Ye, Chen, Chen, \& Cui, 2013), the strong effect of salinity on the hydraulic conductivity in organic soils has to our knowledge not been shown in earlier studies. This effect is probably due to the combination of physicochemical effects (pore dilation) and biogeochemical effects (depressed methanogenesis).

An extrapolation of the findings in the present paper, based on a long term field experiment, on a landscape scale is difficult to make. Our study, however, shows that increased salinity not only influences physical and biogeochemical processes but as a result also affects hydrological processes in the phreatic layer. Our study also provides a robust methodological approach for measuring influences of physical and biogeochemical processes on the hydraulic conductivity. Future models and predictions of effects of climate change and increased salinization induced by sea level rise on water resources would therefore benefit from incorporating both physicochemical and biogeochemical processes. This would improve our understanding of the effects of increased salinity on hydrological processes. Our findings stress the need for an interdisciplinary approach to understand processes in terms of multiphase (liquid-gas) flow with shifting chemical equilibria in the hyporheic zone of wetlands threatened by salinization.

\section{ACKNOWLEDGMENTS}

We would like to thank R. Loeb, P.J. Westendorp and M. Klinge for help with the set-up and management of the study. We would like to acknowledge R. Kuiperij, J. Graafland, D. Verheijen, P. van der Ven, J. Eijgensteijn, S. Krosse for assistance in the field and the lab. We acknowledge Landschap Noord-Holland for their permission to carry out research in the llperveld and N. Hogeweg, F. de Vries, N. Dekker, C. Hartman, L. Vaal, B. van de Riet, J. Abma and O. Steendam for assistance in the field and field relevant information. Furthermore, we wish to thank the anonymous reviewers which greatly helped us to improve our manuscript. This research project was partly funded by the national research program $\mathrm{O}+\mathrm{BN}$ of the Dutch Ministry of Economic Affairs, Agriculture and Innovation.

\section{REFERENCES}

Abarca, E., \& Post, V. (2010). Saltwater and freshwater interactions in coastal aquifers. Hydrogeology Journal, 18, Special Issue. doi:10.1007/ s10040-009-0561-9.

Baird, A. J., Eades, P. A., \& Surridge, B. W. J. (2008). The hydraulic structure of a raised bog and its implications for ecohydrological modelling of bog development. Ecohydrology, 1, 289-298.

Baird, A. J., \& Gaffney, S. W. (1995). A partial explanation of the dependency of hydraulic conductivity on positive pore water pressure in peat soils. Earth Surface Processes and Landforms, 20(6), 561-566.

Baird, A. J., Surridge, B. W. J., \& Money, R. P. (2004). An assessment of the piezometer method for measuring the hydraulic conductivity of a Cladium mariscus - Phragmites australis root mat in a Norfolk (UK) fen. Hydrological Processes, 18, 275-291.

Baird, A. J., \& Waldron, S. (2003). Shallow horizontal groundwater flow in peatlands is reduced by bacteriogenic gas production. Geophysical Research Letters, 30, 2043.
Bakker, M., \& Van Smeerdijk, D. G. (1982). A palaeoecological study of a Late Holocene section from "Het Ilperveld", western Netherlands. Review of Palaeobotany and Palynology, 36, 95-163.

Baldwin, D. S., Rees, G. N., Mitchell, A. M., Watson, G., \& Williams, J. (2006). The short-term effects of salinization on anaerobic nutrient cycling and microbial community structure in sediment from a freshwater wetland. Wetlands, 26, 455-464.

Barlett, K. B., Bartlett, D. S., Hariss, R. C., \& Sebacher, D. I. (1987). Methane emissions along a salt marsh salinity gradient. Biogeochemistry, 4(3), 183-202.

Beckwith, C. W., \& Baird, A. J. (2001). Effect of biogenic gas bubbles on water flow through poorly decomposed blanket peat. Water Resources Research, 37, 551-558.

Boelter, D. H. (1969). Physical properties of peat as related to degree of decomposition. Soil Science Society of America, 33, 606-609.

Bonte, M., \& Zwolsman, J. J. G. (2010). Climate change induced salinization of artificial lakes in the Netherlands and consequences for drinking water production. Water Research, 44, 4411-4424.

Boulton, A. J., Findlay, S., Marmonier, P., Stanley, E. H., \& Valett, H. M. (1998). The functional significance of the hyporheic zone in streams and rivers. Annual Review of Ecology and Systematics, 29, 59-81.

Bouwer, H., \& Rice, R. C. (1976). Slug test for determining hydraulic conductivity of unconfined aquifers with completely or partially penetrating wells. Water Resources Research, 12, 423-428.

Bouwer, H. (1989). The Bouwer and Rice slug test - an update. Ground Water, 27, 304-309.

Brown, D. L., Narasimhan, T. N., \& Demir, Z. (1995). An evaluation of the Bouwer and Rice method of slug test analysis. Water Resources Research, 31, 1239-1246.

Butler, J. J. (1998). The design, performance, and analysis of slug tests. Boca Roton, Florida, US: Lewis Publishers.

Cappenberg, T. E. (1975). A study of mixed continues cultures of sulfatereducing and methane producing bacteria. Microbial Ecology, 2, 60-72.

Chambers, L. G., Reddy, K. R., \& Osborne, T. Z. (2011). Short-term response of carbon cycling to salinity pulses in a freshwater wetland. Soil Science Society of America Journal, 75, 2000-2007.

Chason, D. B., \& Siegel, D. I. (1986). Hydraulic conductivity and related physical properties of peat, Lost River peatland, northern Minnesota. Soil Science, 142, 91-99.

Comas, X., \& Slater, L. (2004). Low-frequency electrical properties of peat. Water Resources Research, 40, W12414.

Cooper, H. H., Bredehoeft, J. D., \& Papadopulos, I. (1967). Response of a finite-diameter well to an instantaneous charge of water. Water Resources Research, 3, 263-269.

De Beaufort LF. 1954. Veranderingen in de Flora en Fauna van de Zuiderzee (thans ljsselmeer) na de Afsluiting in 1932, C. de Boer Jr

De Louw, P. G. B., Eeman, S., Siemon, B., Voortman, B. R., Gunnink, J., Van Baaren, E. S., \& Oude Essink, G. H. P. (2011). Shallow rainwater lenses in deltaic areas with saline seepage. Hydrology and Earth System Sciences, 8, 7657-7707.

De Louw, P. G. B., Oude Essink, G. H. P., Stuyfzand, P. J., \& Van der Zee, S. E. A. T. M. (2010). Upward groundwater flow in boils as the dominant mechanism of salinization in deep polders, the Netherlands. Journal of Hydrology, 394, 494-506.

De Louw, P. G. B., Vandenbohede, A., Werner, A. D., \& Oude Essink, G. H. P. (2013). Natural saltwater upcoming by preferential groundwater discharge through boils. Journal of Hydrology, 490, 74-87.

Denier van der Gon, H. A. C., \& Neue, H. U. (1995). Methane emission from a wetland ricefield as affected by salinity. Plant and Soil, 170, 307-313.

Frenkel, H., Goertzen, J. O., \& Rhoades, J. D. (1977). Effects of clay type and content, exchangeable sodium percentage, and electrolyte concentration on clay dispersion and soil hydraulic conductivity. Soil Science Society of America Journal, 42, 32-39. 
Gevantman, L. H. (1999). Solubility of selected gases in water. In D. R. Lide (Ed.), CRC handbook of chemistry and physics, 1999-2000 (80th ed.). (pp. 8-86-8-90). Boca Raton, Florida: CRC Press.

Herbert, E. R., Boon, P., Burgin, A. J., Neubauer, S. C., Franklin, R. B., Ardón M., ... Gell, P. (2015). A global perspective on wetland salinization: ecological consequences of a growing threat to freshwater wetlands. Ecosphere, 6(10), 206 .http://dx.doi.org/10.1890/ES14-00534.1

Hoag, R. S., \& Price, J. S. (1997). The effects of matrix diffusion on solute transport and retardation in undisturbed peat in laboratory columns. Journal of Contaminant Hydrology, 28, 193-205.

Holzbecher, E. (1998). Modeling density-driven flow in porous media, principles, numerics, software. ( pp. 286). Berlin Heidelberg: Springer Verlag.

Hvorslev MJ. 1951. Time lag and soil permeability in groundwater observations, waterways experimental station bulletin 36. U.S. Army Corps of Engineers: Vicksburg, Mississippi; 50.

Hyder, Z., Butler, J. J., McElwee, C. D., \& Liu, W. Z. (1994). Slug tests in partially penetrating wells. Water Resources Research, 30, 2945-2957.

Hyder, Z., \& Butler, J. J. (1995). Slug tests in unconfined formations - an assessment of the Bouwer and Rice technique. Ground Water, 33, 16-22.

Katerji, N., Van Hoorn, J. W., Hamdy, A., \& Mastrorilli, M. (2003). Salinity effect on crop development and yield, analysis of salt tolerance according to several classification methods. Agricultural Water Management, 62, 37-66.

Kellner, E., Baird, A. J., Oosterwoud, M., Harrison, K., \& Waddington, J. M. (2006). The effect of temperature and atmospheric pressure on methane $(\mathrm{CH} 4)$ ebullition from near-surface peats. Geophysical Research Letters, 33, L18405.

Kellner, E., Price, J. S., \& Waddington, J. M. (2004). Pressure variations in peat as a result of gas bubble dynamics. Hydrological Processes, 18, 2599-2605.

Kettridge, N., \& Binley, A. (2010). Evaluating the effect of using artificial pore water on the quality of laboratory hydraulic conductivity measurements of peat. Hydrological Processes, 24, 2629-2640.

Kettridge, N., Kellner, E., Price, J. S., \& Waddington, J. M. (2012). Peat deformation and biogenic gas bubbles control seasonal variations in peat hydraulic conductivity. Hydrological Processes, 27, 3208-3216.

Kill DL. 1990. Monitoring well development - Why and how. In: Ground water and vadose zone monitoring. Nielsen, DM, Johnson, Al (eds). ASTM STP 1053, American society for testing and materials, Philadelphia, PA, pp 82-90.

KNMI, http://www.klimaatatlas.nl (The Royal Netherlands Meteorological Institute, 2015)

Lamers, L. P. M., Falla, S. J., Samborska, E. M., Van Dulken, L. A. R., Van Hengstum, G., \& Roelofs, J. G. M. (2002b). Factors controlling the extent of eutrophication and toxicity in sulfate-polluted freshwater wetlands. Limnology and Oceanography, 47, 585-593.

Lamers, L. P. M., Farhoush, C., Van Groenendael, J. M., \& Roelofs, J. G. M. (1999). Calcareous groundwater raises bogs; the concept of ombrotrophy revisited. Journal of Ecology, 87, 639-648.

Lamers, L. P. M., Smolders, A. J. P., \& Roelofs, J. G. M. (2002a). The restoration of fens in the Netherlands. Hydrobiologia, 478, 107-130.

Legates, D. R., Mahmood, R., Levia, D. F., DeLiberty, T. L., Quiring, S. M., Houser, C., \& Nelson, F. E. (2011). Soil moisture: A central and unifying theme in physical geography. Progress in Physical Geography, 35, 65-86.

Mandal, U. K., Bhardwaj, A. K., Warrington, D. N., Goldstein, D., Bar Tal, A., \& Levy, G. C. (2008). Changes in soil hydraulic conductivity, runoff, and soil loss due to irrigation with different types of saline-sodic water. Geoderma, 144, 509-516.

Marinas, M., Roy, J. W., \& Smith, J. E. (2013). Changes in entrapped gas content and hydraulic conductivity with pressure. Groundwater, 51, 41-50.

McNeal, B. L. (1967). Prediction of the effect of mixed-salt solutions on soil hydraulic conductivity. Soil Science Society of America Journal, 32, 190-193.
Mehnert, E., \& Jennings, A. A. (1985). The effect of salinity dependent hydraulic conductivity on saltwater intrusion episodes. Journal of Hydrology, 80, 283-297.

Nelen \& Schuurmans Consultants (2005). Modelstudie Ilperveld, HF0043.1, Utrecht.

Nielsen, D. L., Brock, M. A., Crosslé, K., Harris, K., Healey, M., \& Jarosinski, I. (2003). The effects of salinity on aquatic plant germination and zooplankton hatching from two wetland sediments. Freshwater Biology, 48, 2214-2223.

Nieuwenhuis, H. S., \& Schokking, F. (1997). Land subsidence in drained peat areas of the province of Friesland, the Netherlands. Quarterly Journal of Engineering Geology and Hydrogeology, 30, 37-48.

Nijp J. J. 2015. Fine scale ecohydrological processes in northern peatlands and their relevance for the carbon cycle. PhD Thesis. Wageningen University, Wageningen.

Ong, J. B., \& Zlotnik, V. A. (2011). Assessing lakebed hydraulic conductivity and seepage flux by potentiomanometer. Groundwater, 49, 270-274.

Orghidan, T. (1959). Ein neuer Lebensraum des unterirdischen Wassers: der hyporheische Biotop. Archiv für Hydrobiologie, 55, 392-414.

Oude Essink, G. H. P., \& Kooi, H. (2011). Land subsidence and sea level rise threaten fresh water resources in the coastal groundwater system of the Rijnland water board. In The Netherlands, climate change effects on groundwater resources: A global synthesis of findings and recommendations)CRC Press.

Oude Essink, G. H. P., Van Baaren, S., \& De Louw, P. G. B. (2010). Effects of climate change on coastal groundwater systems: A modeling study in the Netherlands. Water Resources Research, 46, W0OF04.

Ours, D. P., Siegel, D. I., \& Glaser, P. H. (1997). Chemical dilation and the dual porosity of humified bog peat. Journal of Hydrology, 196, 348-360.

Pitman, M. H., \& Lauchli, A. (2002). Global impact of salinity and agricultural ecosystems. In A. Läuchli, \& U. Lüttge (Eds.), Salinity: Environment Plants - Molecules. (pp. 3-20). Printed in the Netherlands: Kluwer Academic Publishers.

R Core Team (2014). R: A language and environment for statistical computing, R-Foundaton for Statistical Computing, Vienna, Austria. http://www.R-project.org/

Remane, A., \& Schlieper, C. (1958). Biologie des Brackwassers. Die Binnengewässer, 22, 1-348.

Rengasamy, P. (2006). World salinization with emphasis on Australia. Journal of Experimental Botany, 57, 1017-1023.

Rengasamy, P. (2010). Soil processes affecting crop production in saltaffected soils. Functional Plant Biology, 37, 613-620.

Reynolds, W. D., Brown, D. A., Mathur, S. A., \& Overend, R. P. (1992). Effect of in-situ gas accumulation on the hydraulic conductivity of peat. Soil Science, 153, 397-408.

Salhotra, A. M., Adams, E. E., \& Harleman, R. F. (1985). Effect of salinity and ionic composition on evaporation: Analysis of dead sea evaporation pans. Water Resources Research, 9, 133-134.

Schothorst, C. J. (1977). Subsidence of low moor peat soils in the western Netherlands. Geoderma, 17, 265-291.

Segers, R. (1998). Methane production and methane consumption: A review of processes underlying wetland methane fluxes. Biogeochemistry, 41, 23-51.

Singh, A. P., Singh, A., Tiwari, H. L., \& Dwivedi, P. K. (2011). The effect of salts of the hydraulic conductivity of the saline alkali soil. Indian Journal Scientific Research, 4, 117-119.

Sluijter, R., Leenaers, H., \& Camarasa, M. M. (2011). De Bosatlas van het klimaat (pp. 112). Groningen, The Netherlands: Noordhoff Atlasproducties.

Smolders, A. J. P., Tomassen, H. B. M., Lamers, L. P. M., Lomans, B. P., \& Roelofs, J. G. M. (2002). Peat bog restoration by floating raft formation: The effects of groundwater and peat quality. Journal of Applied Ecology, 39, 391-401. 
Strack, M., Kellner, E., \& Waddington, J. M. (2005). Dynamics of biogenic gas bubbles in peat and their effects on peatland biogeochemistry. Global Biogeochemical Cycles, 19, GB1003. doi:10.1029/ 2004GB002330

Stofberg, S. F., Van Engelen, J., Witte, J. P. M., \& Van der Zee, S. E. A. T. M. (2016). Effects of root mat buoyancy and heterogeneity on floating fen hydrology. Ecohydrology. doi:10.1002/eco.1720

Storey, R. G., Fulthorpe, R. R., \& Williams, D. D. (1999). Perspectives and predictions on the microbial ecology of the hyporheic zone. Freshwater Biology, 41, 119-130.

Surridge, B. W. J., Baird, A. J., \& Heathwaite, A. L. (2005). Evaluating the quality of hydraulic conductivity estimates from piezometer slug tests in peat. Hydrological Processes, 19, 1227-1244.

Thiem, G. (1906). Hydrologische Methoden. Leipzig, Germany: Gebhardt.

Van Beers, W. F. J. (1983). The auger hole method. In A field measurement of the hydraulic conductivity of soil below the water table, international institute for land reclamation and improvement). The Netherlands: Wageningen.

Van Dijk, G., Smolders, A. J. P., Loeb, R., Bout, A., Roelofs, J. G. M., \& Lamers, L. P. M. (2015). Effects of salinization on nitrogen, phosphorus and carbon biogeochemistry of coastal freshwater wetlands; constant versus fluctuating salinity levels. Biogeochemistry, 126, 71-84.

Van Gemerden, H. (1984). The sulphide affinity of phototrophic bacteria in relation to the location of elemental sulphur. Archiv für Mikrobiologie, 139, 289-294

Velstra, J., Groen, J., \& De Jong, K. (2011). Observations of salinity patterns in shallow groundwater and drainage water from agricultural land in the northern part of the Netherlands. Irrigation and Drainage, 60, 51-58.

Werner, A. D., \& Simmons, C. T. (2009). Impact of sea-level rise on sea water intrusion in coastal aquifers. Ground Water, 47, 197-204.

Weston, N. B., Dixon, R. E., \& Joye, S. B. (2006). Ramifications of increased salinity in tidal freshwater sediments: Geochemistry and microbial pathways of organic matter mineralization. Journal of Geophysical Research, 111, G0100. doi:10.1029/2005JG000071
White, H. (1980). A heteroskedasticity-consistent covariance matrix estimator and a direct test for heteroskedasticity. Econometrica, 48, 817-838.

Whittington, P. N., \& Price, J. S. (2006). The effects of water table drawdown (as a surrogate for climate change) on the hydrology of a fen peatland, Canada. Hydrological Processes, 20, 3589-3600.

Willemsen, J., Van't Veer, R., \& Van Geel, B. (1996). Environmental change during medieval reclamation of the raised-bog area waterland (The Netherlands): A palaeophytosociological approach. Review of Palaeobotany and Palynology, 94, 75-100.

Willmott, C. J., Ackleson, S. G., Davis, R. E., Feddema, J. J., Klink, K. M., Legates, D. R., ... Rowe, C. M. (1985). Statistics for the evaluation and comparison of models. Journal of Geophysical Research, Oceans, 90 , 8995-9005.

Witte, H. J. L., \& Van Geel, B. (1985). Vegetational and environmental succession and net organic production between 4500 and 800 B.P. reconstructed from a peat deposit in the western Dutch coastal area Assendelver Polder. Review of Palaeobotany and Palynology, 45, 239-300.

Yamamoto, S., Alcauskas, J. B., \& Crozier, T. E. (1976). Solubility of methane in distilled water and seawater. Journal of Chemical \& Engineering Data, 21, 78-80.

Zhu, C. M., Ye, W. M., Chen, Y. G., Chen, B., \& Cui, Y. J. (2013). Influence of salt solutions on the swelling pressure and hydraulic conductivity of compacted GMZ01 bentonite. Engineering Geology, 166, 74-80.

Zlotnik, V. A., Goss, D., \& Duffield, G. M. (2010). General Steady-State Shape Factor for a Partially Penetrating Well. Ground Water, 48, 111-116.

How to cite this article: van Dijk G, Nijp JJ, Metselaar K, Lamers LPM, Smolders AJP. Salinity-induced increase of the hydraulic conductivity in the hyporheic zone of coastal wetlands. Hydrological Processes. 2017;31:880-890. doi: 10.1002/hyp.11068 